\title{
In the Time of Many Epidemies, is it also the Time to Restore the Cropping Genetic Diversity?
}

ISSN: 2637-7659

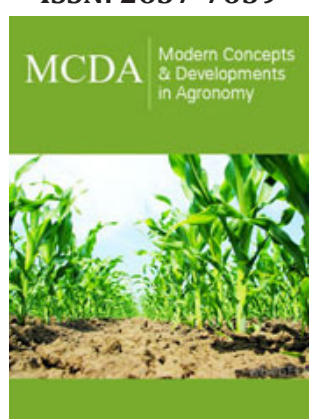

*Corresponding author: Rubens Onofre Nodari, Graduate Program on Plant Genetic Resources, Universidade Federal de Santa Catarina, Florianópolis, SC, Brazil

Submission: 偰 May 11, 2020

Published: 眥 May 19, 2020

Volume 6 - Issue 2

How to cite this article: Rubens Onofre Nodari. In the Time of Many Epidemies, is it also the Time to Restore the Cropping Genetic Diversity?. Mod Concep Dev Agrono. 6(2). MCDA. 000635. 2020. DOI: 10.31031/MCDA.2020.06.000635

Copyright@ Rubens Onofre Nodari, This article is distributed under the terms of the Creative Commons Attribution 4.0 International License, which permits unrestricted use and redistribution provided that the original author and source are credited.

\section{Rubens Onofre Nodari*}

Graduate Program on Plant Genetic Resources, Universidade Federal de Santa Catarina, Florianópolis, Brazil

\begin{abstract}
The $20^{\text {th }}$ century is remarkable in terms of replacement of management practices and technologies in agricultural systems. One of the major ones, was the substitution of genetically heterogeneous varieties by highly inbreed or pure lines of hybrids. Such narrow genetic base in cropping field, together with the scaling up in cultivated area, allowed the creation of the vulnerability conditions, which facilitate the occurrence of epidemics or decrease in resilience. As a result, there were catastrophic yield drop in many places and times, associated with plant disease epidemics or adverse climatic events. To overcome that vulnerability, genetic variability can be increase by means of seed mixture, multiline or agroforestry systems, which can be used in combination with the agro ecological principles.
\end{abstract}

\section{Introduction}

From domestication times up to $19^{\text {th }}$ century the cultivated varieties were landraces that genetically are heterogeneous. Pure line selection from a landrace allowed narrowing the genetic variability of a variety. During the $20^{\text {th }}$ century, crosses followed by selfing end up with highly inbreed or pure line, which became a new variety in autogamous species. The same procedure followed by crosses generated the single hybrid is alogamous species. In both cases the varieties are highly or totally genetically uniform [1].

There are reasons why that extremely distinct approach was adopted. A pure line mentality was developed, "convinced that variation was bad, uniformity was good, and offtypes in the field somehow immoral" [1]. According Harlan [1], that is how we are open to epidemics of serious diseases. Harlan JR was not alone; the United States National Research Council stated that uniformity derives from powerful economic and legislative forces, even though that it is expected that genetic uniformity is the basis of vulnerability to epidemics [2].

\section{Implications of the genetic uniformity}

As human society, we experienced hundreds of very important disasters due to crop genetic vulnerability. In United States of America, the 1970 yield of corn fallen approximately 50 percent in some southern states and 15 percent nationwide due to the epidemy of the corn blight [2].The miserable potato yield in the autumn of 1846 was an outright disaster: three-quarters of the crop had been destroyed by the blight in Ireland [3]. "Ireland great Famine" tragedy happens because the higher yield variety-such as "Lumper" that was almost universally grown in Ireland succumbed by potato blight [4]. Take into account many episodes of epidemies largely due the lack of genetic diversity in cultivated crops the "Genetic Vulnerability of Major Crops" was an early warning aa well the Harlan article, both published in the same year, 1972. There are also many other consequences. Monoculture of a highly uniform pure line or a single hybrid derived of two endo gamic lines cultivated in large scale in a humid and hot climate conditions creates the "genetic vulnerability" conditions that favor the occurrence of pest, sometimes epidemies, and consequently, the escalating use of 
pesticides. In addition to increase the production costs, pesticides contaminate food and the environment. In the south of Brazil, the spillover (derive) of glyphosate or 2-4, D based herbicides applied over one crop (say genetically modify soybean varieties), is causing mortality or plant depletion of vineyards for example, reducing grape production and breaking the social cohesion.

\section{Benefits of genetic variability in the cropping systems}

Many scholars advised that diversity in cultivation were better than genetically uniform stand. Darwin was the pioneer: "It has been experimentally proved, that if a plot of ground be sown with several distinct genera of grasses, a greater number of plants and a greater weight of dry herbage can thus be raised. The same has been found to hold good when first one variety and then several mixed varieties of wheat have been sown on equal spaces of ground [5]. Last year the Darwin statement was proved again: a global study showed evidence the biodiversity-mediated benefits for crop production [6]. The intra-specific and inter-specific diversity is one of the basic principles of the agroecology [7], but not of other agricultural systems. Even under the scope of the industrial or chemically intensive agricultural systems there are many solutions to minimize the effects of the current dangerous and vulnerable monoculture of uniform varieties. One of them is the development of resistant variety by combining resistant pest genes that are present in distinct plant accessions of the same or other closed related species. In addition, there are several management practices that also can minimize the consequences of the use of genetically uniform varieties.

\section{Multiline and seed mixture to face disease and support}

However, other solutions include the adoption of agroecology principles and processes, as the base of sustainable agricultural system, and their relationship with social cohesion and consumers, through the production of safe and high biological products. Alternatively, seed mixtures or landraces (varieties with distinct allelic combinations or genotypes) have been successfully used to decrease the severity of diseases. Both seed mixing and multiline $[8,9]$ have been proved superior to pure lines to resist plant diseases. Comparatively to pure line in field tests, multiline reduced the severity of anthracnose (Colletotrichum sublineolum) in sorghum [10], the progress of anthracnose (Colletotrichum lindemuthianum) in common bean [11], and as a mean of disease control in many path systems [12]. In the same way, comparatively to pure lines, seed mixtures also were able to drastically reduce blast (Magnaporthe grisea) an increase yield in rice [13] and increase yield up to $50 \%$ in coffee [14]. The review done by [15] revealed that there were examples of seed mixtures that substantiate both low and high degrees of disease control for a wide range of path systems, including for pathogens that insect vectored. Twenty years ago, it was asked-why isn't everybody growing them? [16]. Since almost thousands of years of landrace or seed mixtures use and 70 years after multiline approach suggested to maintain a broad genetic base under cropping, it is time to ask again why not use multiline and/or seed mixture to face plant disease? The objection raised such as heterogeneity can difficult verification, affects customer preference, low quality of the components, among others [16], were related to cereals, mainly barley to produce malt.

\section{Conclusion}

As pointed out by Harlan JR [1], the line between abundance and disaster is becoming thinner and thinner, agronomist, scholars and farmers should be aware and concerned that epidemies frequency will increase in near future due to the large cropping area, cropping of narrow genetic base cultivars and effects of climate changes that favor the spread and reproduction of disease and pests. Agroecologist farmers are obtaining successful harvests even under biotic and abiotic stresses, without impoverishing the soil and contaminating the environment with agrochemicals. In addition to the agro ecological principles, they use landraces and seed mixtures, as well as multi-cropping species systems.

\section{References}

1. Harlan JR (1972) Genetics of disaster. Journal of Environment Quality 1(3): 212-215.

2. National Research Council (1972) Genetic vulnerability of major crops. National Academy of Sciences, Washington, DC, USA.

3. Cousens SH (1960) Regional death rates in Ireland during the great famine, from 1846 to 1851. Population Studies 14(1): 55-74.

4. Bourke A, Lamb H (1993) The spread of potato blight in Europe in 18456 and the accompanying wind and weather patterns. Meteorological service, Dublin, Ireland p. 66.

5. Darwin C (1859) On the origin of species by means of natural selection or the preservation of favored races in the struggle for life. John Murray, London.

6. Dainese M, Martin EA, Aizen MA, Albrecht M, Bartomeus I, et al. (2019) A global synthesis reveals biodiversity-mediated benefits for crop production. Sci Adv 5(10).

7. Nicholls CI, Altieri MA, Vazquez L (2016) Agroecology: principles for the conversion and redesign of farming systems. J Ecosys Ecograph S5(1): 010 .

8. Rozen HR (1949) Oat parentage procedures for combining resistance to crown rust, including race 45 , and Helmintosporium blight. Phytopath 39: 20.

9. Jensen NF (1952) Intravarietal diversification in oat breeding. Agron J 44(1): 30-34.

10. Costa RV, Zabolim L, Silva DD, Cota LV, Casela CR (2012) Utilização de multilinhas dinâmicas para o manejo da antracnose do sorgo. Pesquisa Agropecuária Brasileira 47(2): 173-180.

11. Botelho FBS, Ramalho MAP, Abreu AFB, Rosa HJA (2011) Multiline as a strategy to reduce damage caused by Colletotrichum lindemuthianum. Journal of Phytopathology 159(3): 175-180.

12. Browning A, Frey J (1969) Multiline cultivars as a means of disease control. Annu Rev Phytopathol 7: 355-382.

13. Zhu Y, Chen H, Fan J, Wang Y, Li Y, et al. (2000) Genetic diversity and disease control in rice. Nature 406: 718-722.

14. Nogueira AM, Carvalho SP, Bartholo GF, Mendes ANG (2005) Avaliação da produtividade e vigor vegetativo de linhagens das cultivares catuaivermelho e catuai-amarelo (Coffea arabica L.) Plantadas individualmente e em diferentes combinações. Revista Ciência e Agrotenologia 29(1): 2733. 
15. Mundt CC (2002) Use of multiline cultivars and cultivar mixtures for disease management. Annu Rev Phytopathol 40: 381-410.
16. Newton AC, Swanston JS (1999) Cereal variety mixtures reducing inputs and improving yield and quality-why isn't everybody growing them? Scottish Crop Research Institute Annual Report for 1998/99 pp. 55-59.

For possible submissions Click below: 